\title{
Comparative Study of Heat Stress Effect on Thermoregulatory and Physiological Responses of Baladi and Shami Goats in Egypt Younis, F. E. ${ }^{1}$; M. A. Basyony ${ }^{2}$; S. S. Abou-Elezz ${ }^{1}$; Y. E. El-Bolkiny ${ }^{2}$ and S. T. El-Shehry ${ }^{1}$ \\ ${ }^{1}$ Animal and Poultry Physiology Department, Desert Research Center \\ ${ }^{2}$ Zoology department, Faculty of science, Tanta University
}

\begin{abstract}
The experimental study was managed to achieve the effect of heat stress on bodyweight, thermoregulatory and physiological responses of Baladi and Shami goats. Twenty adult female Baladi and Shami goats (10 of Baladi goats and 10 of Shami goats) were used for the study. The goats were exposed to three different times (T1, T2 \& T3) of temperaturetreatment; $\mathrm{T} 1, \mathrm{~T} 2$ in August and T3 in September, Baladi and Shami goats were divided into two exposed groups to solar radiation $(\mathrm{n}=10)$. The results showed that 1 periods was significantly $(\mathrm{P}<0.05)$ increased in relative humidity, while T2 period was significantly $(\mathrm{P}<0.05)$ increasedin ambient temperature and temperature-humidity index. Bodyweight showed a significant $(\mathrm{P}<0.05)$ decrease at $\mathrm{T} 3$ in both breeds. Baladi goats showed a significant $(\mathrm{P}<0.05)$ increase at $\mathrm{T} 2$ compared to Shami goats in rectal and skin temperature, respiratory rate, white blood cells, albumin, serum ALT, and phosphorus. While Shami goats showed increase in coat and Ear temperatures, also, total protein, AST and CL at T1 compared with Baladi goats. It is accomplished that heat stress had a significant increaseeffect on body weight,thermoregulatory and physiological responses on Shami goats compared with Baladi goats.
\end{abstract}

Keywords: Goats, heat stress, thermoregulatory, bodyweight, physiology.

\section{INTRODUCTION}

It is well known that ambient temperature is high in tropical and semitropical zones,it consideredthe major factor on animal function mechanism and body temperature. Despite small ruminants having well developed mechanism of thermoregulation, they do not maintain strict homeothermy under heat stress (Silanikove, 2000 and Tushar et al., 2017).

small ruminants are considered the most important resources of small ruminant in the tropical regions (Ozung et al., 2011 and Okoruwa, 2014). Tropical regions characterized with a variation of different climatic conditions that give altitude to different adaptive mechanisms so that goats could overcome stresses of environmental conditions in tropics (Okoruwa, 2014). Baladi local goats are very adapted to environmental conditions of the north Sinai desert, which include a prolonged dry season, extreme climate fluctuations, and water scarcity (Helal et al., 2010b). However, there have been a lot of efforts to introduce Shami breed for crossbreeding with local Baladi breeds or used as a straight-breeds for more milk production (Helal et al., 2010a). The physiological reaction of goats to ecological stress during moisten and arid season showed athorough effects on bodyweight, thermoregulatory and physiological responses (Okoruwa, 2014). Recently ,many studies suggested thermo-physiological parameters to observe animal interest in hard environment such as rectal temperature, respiratory rate and blood parameters (Helal et al., 2010a; Sanusi et al., 2010). The ability of goats to maintain heat adaptationto hard environmental lacksneeds to be studied. Heat stress with high climatic conditions and relative humidity with extended exposure to direct solar radiation is more mutual especially in arid season (Okoruwa, 2014). Thus, heat stress effected on physiological balance of goats and theirendocrine, nervous and immunesystems that have been involved with responses and alternate regulatory performance (Castanheira et al., 2010). Changes in blood result of goats are delicate to environmental temperature variation, being an important indicator of physiological responses to stressing factor. The present data was infectious to investigate heat stress effects onbodyweight, thermoregulatory and physiological responses of Baladi and Shami goats.

\section{MATERIALS AND METHODS}

Place of experiment: The present study was executed at RaesSedr Research Station, belonging to Desert Research Center, Southern Sinai, and Egypt.

Animals and Experimental Design:

Twenty adult Baladi and Shami goats were randomly chosen from the breeding flock of the station (10 of Baladi goats and 10 of Shami goats). All goats were healthy and were kept under semiopen pens. The animals were allowed to adapt in the sheltered pens conditions ( 7 days) as adaptation period, no measurements were taken during this period. The two breeds were divided into 2 groups, 10 animals in each.

Goats were exposed daily to solar radiation from 5:00 am to 7:00 pm throughout the experimental period. Data were collected three times: time 1 (T1) at 1 August, time 2 (T2) at 15 August and time 3 (T3) at 1 September. Animals were fed twice daily (9:00 am and 15:00 pm) with alfalfa hay $a d$. Lib and supplemented with concentrate mixture (0.5 $\mathrm{kg} /$ head/day). Drinking water was available all day.

\section{Collected of Data}

Metrological data: Ambient temperature (AT, ${ }^{\circ} \mathrm{C}$ ) and relative humidity (RH\%) were measured at $2.00 \mathrm{pm}$ (afternoon) using a thermometer, throughout the experiment. Temperature-humidity index (THI) was calculated by using the formula below as reported by Amundson et al. (2006).

$\mathrm{THI}=0.8 \mathrm{XAT} .{ }^{\circ} \mathrm{C}+\left(\left(\mathrm{RH}^{\circ} \div \mathbf{1 0 0}\right) \mathrm{X}\left(\mathrm{AT}^{\circ} \mathrm{C}-14.4\right)\right)+46.6$ 
Thermoregulatory and Body weight results: Bodyweight (BW, Kg) of goats was measured through all experimental period in each group. Respiratory rate and rectal, skin, coat and ear temperature in each goat were measured at 2:00pm. Digital thermometer was used to measured rectal temperature, with a disinfected sensory tip and inserted into the rectum at the display of $L^{\circ} \mathrm{C}$ by the thermometer (which indicated that the thermometer is set for the reading temperature) and was removed after the sound of the alarm signal, then recorded body temperature. Skin, coat and ear temperature were measured using infrared thermometer in four shaved regions (right and left shoulder with right and left hips). Respiratory rate was determined by counting the number of abdominal movement per minute.

Physiological Data: Two different $(5 \mathrm{ml})$ vacuum tubes used for blood samples which taken up from jugular vein from each animal. One of the $(5 \mathrm{ml})$ set of blood tubes contained ethylene diamine tetraacetic acid (anti-coagulant) for haematological studies. The haemoglobin $(\mathrm{Hb}, \mathrm{g} / \mathrm{dl})$, red blood cell $\left(R B C \times 10^{12} / L\right)$, hematocrit (HCT \%) and white blood cell $\left(W B C \times 10^{9} / L\right)$ were analysed as described by AlEissa and Alkahtani (2011); Okoruwa and Ikhimioya (2014)

The second $(5 \mathrm{ml})$ vacuum set of blood tubes without anticoagulant were centrifuged for 20 minute at $3500 \mathrm{rpm}$ to collect serum and stored at $-20^{\circ} \mathrm{C}$ for chemical analysis. Total plasma proteins (TP, g/dl), albumin concentration (Al, g/dl) was determined according to the method reported by Helal et al. (2010). Alanine transferase (ALT, u/ml), aspartate transferase (AST, u/ml) by Swarup et al., 2007 and Sanusi et al. (2010), sodium $\left(\mathrm{Na}^{+}, \mathrm{mmol} / \mathrm{L}\right)$, chloride $\left(\mathrm{Cl}^{-}, \mathrm{mmol} / \mathrm{L}\right)$, calcium $\left(\mathrm{Ca}^{+2}, \mathrm{mmol} / \mathrm{L}\right)$ and potassium $\left(\mathrm{K}^{+}, \mathrm{mmol} / \mathrm{L}\right)$ were estimated according to the way reported by Al-Haidary et al. (2012).

Statistical Analysis: Data for each of body weight, thermoregulatory and physiological indices were analyzed using the Generalized Liner Model (GLM) of SAS (2003) software package. Statistical means were compared using Duncan Multiple Range Test (DMRT) Duncan, (1955).

\section{RESULTS AND DISCUSSION}

Table 1 showed climatic means value of ambient temperature $\left(\mathrm{AT},{ }^{\circ} \mathrm{C}\right)$, relative humidity $(\mathrm{RH}$, $\%$ ) and temperature-humidity index (THI) for the empirical periods of experiment. for $\mathrm{T} 2\left(42^{\circ} \mathrm{C}\right)$ showed a significant $(\mathrm{P}<0.05)$ increase compared in ambient temperature compared with $\mathrm{T} 1\left(40^{\circ} \mathrm{C}\right)$ and $\mathrm{T} 3$ $\left(38^{\circ} \mathrm{C}\right)$. In this study the ambient temperature for $\mathrm{T} 2$ (in the same time / year) for species showed a higher value than the critical temperature $\left(24\right.$ to $\left.27^{\circ} \mathrm{C}\right)$ indicated by Helal et al. (2010a). The observed relative humidity indicated a significant $(\mathrm{P}<0.05)$ lower values (32 and 38\%)at T2 compared withT1 and T3. The obtained relative humidity data at this experiment showed high value compared with the values $(9.20$ to $33.93 \%)$ recorded by Al-Haidary et al. (2013). The observed data of temperature-humidity index was88.33, 98.25 and 84.93 forT1, T2 and T3,respectively were recorded. Temperature humidity index observed in $\mathrm{T} 1$ and $\mathrm{T} 3$ showed a significant $(\mathrm{P}<0.05)$ decrease than $\mathrm{T} 2$. Temperature humidity index values of 74 or less take into consideration inbred, and 75 to 78 is ultimatum case, while 79 to 83 is dangerous case and equal to or above 84 of temperature-humidity index is a critical case as indicated by Helal et al. (2010). The present study showed that the temperature-humidity index at $\mathrm{T} 1$, T2 and T3 was over than during the empirical periods and distributed as a result to heat stress. Consequently, the climatic results detected that exposed goats to direct sunlight pressure during all periods of this study showed highly heat stressed.

Table 1. Data of climatic parameters recorded during the study periods

\begin{tabular}{lcccc}
\hline $\begin{array}{l}\text { Climatic } \\
\text { parameters }\end{array}$ & T1 & T2 & T3 & $\begin{array}{c}\text { SEM } \\
\pm\end{array}$ \\
\hline $\begin{array}{l}\text { Ambient } \\
\text { temperature }\left({ }^{\circ} \mathrm{C}\right)\end{array}$ & $40^{\mathbf{b}}$ & $42^{\mathbf{a}}$ & $38^{\mathbf{c}}$ & 0.54 \\
$\begin{array}{l}\text { Relative } \\
\text { humidity (\%) }\end{array}$ & $38^{\mathbf{a}}$ & $32^{\mathbf{c}}$ & $37^{\mathbf{b}}$ & 0.32 \\
$\begin{array}{l}\text { Temperature } \\
\text { humidity index }\end{array}$ & $88.33^{\mathbf{b}}$ & $98.25^{\mathbf{a}}$ & $84.93^{\mathbf{c}}$ & 0.21
\end{tabular}

a,b,c Means within the same row with different superscripts differ significantly $(P<0.05)$.

$\mathrm{SEM}=$ Standard error of mean

Table 2. Data of thermoregulatory and body weight parameters on Baladi and Shami goats as affected by heat stress

\begin{tabular}{|c|c|c|c|c|c|c|c|}
\hline \multirow{3}{*}{ Parameters } & \multicolumn{6}{|c|}{ Exposed } & \multirow{3}{*}{ SEM \pm} \\
\hline & \multicolumn{2}{|c|}{ T1 } & \multicolumn{2}{|c|}{ T2 } & \multicolumn{2}{|c|}{ T3 } & \\
\hline & Baladi & Shami & Baladi & Shami & Baladi & Shami & \\
\hline Respiratory rate (breaths/min) & $74.80^{\mathbf{c}}$ & $60.40^{\mathrm{d}}$ & $102^{\mathrm{a}}$ & $95.60^{b}$ & $36.80^{\mathrm{e}}$ & $36.80^{\mathrm{e}}$ & 0.50 \\
\hline Rectal temperature $\left({ }^{\circ} \mathrm{C}\right)$ & $41^{\mathrm{a}}$ & $40.20^{\mathrm{b}}$ & $41^{\mathrm{a}}$ & $40.10^{\mathrm{cb}}$ & $39.82^{\text {cb }}$ & $39.56^{\mathbf{c}}$ & 0.22 \\
\hline Skin temperature $\left({ }^{\circ} \mathrm{C}\right)$ & $39.20^{\mathbf{b a}}$ & $39.20^{\mathbf{b a}}$ & $39.40^{\mathrm{a}}$ & $38.60^{\mathbf{b a}}$ & $38.40^{\mathbf{b c}}$ & $38.20^{\mathbf{b c}}$ & 0.29 \\
\hline Coat temperature $\left({ }^{\circ} \mathrm{C}\right)$ & $40.60^{\mathrm{c}}$ & $46^{\mathrm{a}}$ & $42.60^{\mathrm{b}}$ & $42.60^{\mathbf{b}}$ & $39^{\text {ed }}$ & $39.40^{\mathrm{d}}$ & 0.34 \\
\hline Ear temperature $\left({ }^{\circ} \mathrm{C}\right)$ & $38^{\mathbf{b a}}$ & $38.20^{\mathrm{a}}$ & $38^{\mathbf{b a}}$ & $38.20^{\mathrm{a}}$ & $37.80^{\mathbf{b a}}$ & $37.80^{\mathbf{b a}}$ & 0.26 \\
\hline body weight $(\mathrm{kg})$ & $24.10^{\mathrm{c}}$ & $33.50^{\mathrm{a}}$ & $19.70^{\mathrm{de}}$ & $33.10^{\mathbf{b a}}$ & $21.50^{\mathrm{dc}}$ & $30.20^{\mathbf{b}}$ & 0.95 \\
\hline
\end{tabular}

$\overline{a, b, c, d, e}$ Means within the same row with different superscripts differ significantly $(P<0.05)$.

SEM = Standard error of mean. 
Table 2, showed that thermoregulatory and bodyweight parameters affected with heat stress on Baladi and Shami goats.Respiratory rate showed no significant $(\mathrm{P}>0.05)$ change between Baladi and Shami at T3 $(36.80,36.80$ breaths $/ \mathrm{min})$, but Baladi goats showed increase at T2 (102 breaths/min) and T3 (74.80 breaths/min) compared with Shami goats (95.60 and 74.80 breaths/min), respectively. Rate of respiration could be used as an assessment to inverse the effects of environmental temperature and as an exponent to the stress of heat (Al-Haidary et al. (2012). Rate of respiration is effective and responsible parameter of capacity of the heat and announced that rate of respiration over 12 to 20 breath/minute in small ruminants is a parameter to heat stress (Okourwa et al. (2013). Rectal temperature showed a significant $(\mathrm{P}<0.05)$ increase in Baladi goats at $\mathrm{T} 1$ and $\mathrm{T} 2 \quad\left(41.02^{\circ} \mathrm{C}\right)$ followed by $\mathrm{T} 3$ compared with Shami goats. Rectal temperature increased case consider a better index to heat stress level as reported by Otoikhian et al (2009).Subsequently the observed altitude in the rectal temperature for goats at $\mathrm{T} 1$ and $\mathrm{T} 2$ indicated that, they exposed to heat stress. Skin temperature data of Baladi and Shami goats that were obtained showed a significant $(\mathrm{P}<0.05)$ increase atT1 and $\mathrm{T} 2$ and lowest at $\mathrm{T} 3$. The increase in skin temperature for goats on $\mathrm{T} 1$ and $\mathrm{T} 2$ was also assign to be heat stressed, in which a state of vasodilatation of skin capillary bed has been detected then blood flow increased to surface of skin to favor losing of heat (McManus et al., 2009). Temperature of skin can be also increased due to exposed to direct sunlight, accordingly temperature of skin showed to be fair regarding to levels of ambient solar radiation(Schutz et al., 2011). Therefore, the observed precipitation of respiratory rate of goats at $\mathrm{T} 1$ and $\mathrm{T} 2$ indicated increasing the panting of goats as a result of exposed to high heat stress. Marai et al., 2007 reported that heat loss evaporation mechanism and respiratory hesitation by panting sanatorium to pursue closely the heat loss by evaporation. Shami goats showed a significant $(\mathrm{P}<0.05)$ increase in coat temperature at T1 (46 $\left.{ }^{\circ} \mathrm{C}\right)$ compared with Baladi goats, but they showed no significant effect at T2 and T3. These results concomitant with Helal et al., (2010), who report that Shami goats had highly significant coat depth compared with Baladi goats, and that coat help Shami goats to protect themselves from direct sunlight. On the other hand ear temperature showed no significant effect between the two breeds. Both Baladi and Shami goats induced a significant $(\mathrm{P}>0.05)$ decrease by $\mathrm{T} 3$ compared with $\mathrm{T} 1$ and $\mathrm{T} 2$. Exposed of goats to direct sunlight for 12 hours raised body weight loss of goats (Helal et al. (2010). Lacked in live bodyweight during solar radiation exposure raising energy exhausted to heat waste through evaporation respiratory mechanism and thus to reduce in the water available amount that stored as reported by Ocak et al. (2009).

Table 3. Effect of heat stress on haematological and serum biochemical parameters of exposed Baladi and Shami goats

\begin{tabular}{|c|c|c|c|c|c|c|c|}
\hline \multirow{3}{*}{ Parameters } & \multicolumn{6}{|c|}{ Exposed } & \multirow{3}{*}{$\mathbf{S E M} \pm$} \\
\hline & \multicolumn{2}{|c|}{ T1 } & \multicolumn{2}{|c|}{ T2 } & \multicolumn{2}{|c|}{ T3 } & \\
\hline & Baladi & Shami & Baladi & Shami & Baladi & Shami & \\
\hline \multicolumn{8}{|l|}{ Haematology } \\
\hline $\operatorname{RBCs}\left(10^{12} / \mathrm{L}\right)$ & $10.29^{\mathrm{a}}$ & $10.00^{\mathbf{a b}}$ & $8.78 \mathrm{e}^{\mathbf{b c}}$ & $9.22^{\mathbf{a b}}$ & $8.45^{\mathbf{b c}}$ & $8.30^{\mathbf{c d}}$ & 0.21 \\
\hline $\mathrm{HB}(\mathrm{g} / \mathrm{dl})$ & $9.41^{\mathrm{a}}$ & $8.37^{\mathbf{b}}$ & $8.40^{\mathrm{b}}$ & $7.28^{\text {cd }}$ & $7.96^{\mathrm{c}}$ & $7.26^{\mathrm{cd}}$ & 0.26 \\
\hline $\mathrm{HCT}(\%)$ & $17.46^{\mathrm{a}}$ & $16.52^{\mathrm{bc}}$ & $15.77^{\mathrm{c}}$ & $17.23^{\mathbf{a b}}$ & $14.69^{\text {cd }}$ & $14.20^{\mathrm{d}}$ & 0.68 \\
\hline WBCs $\left(10^{9} / L\right)$ & $11.70^{\mathbf{b a}}$ & $6.42^{\text {ef }}$ & $12.56^{\mathrm{a}}$ & $6.98^{\mathrm{e}}$ & $8.98^{\mathrm{dc}}$ & $9.65^{\mathrm{c}}$ & 0.35 \\
\hline \multicolumn{8}{|l|}{ Serum biochemistry } \\
\hline Total protein $(\mathrm{g} / \mathrm{dl})$ & $8.90^{\mathrm{dc}}$ & $12.37^{\mathrm{a}}$ & $10.30^{\mathbf{b c}}$ & $9.43^{\mathrm{c}}$ & $8.60^{d}$ & $11.36^{\mathbf{b}}$ & 0.42 \\
\hline Albumin $(\mathrm{g} / \mathrm{dl})$ & $2.97^{\mathbf{b}}$ & $3.60^{\mathrm{ba}}$ & $4.33^{\mathrm{a}}$ & $3.83^{\mathrm{b}}$ & $4.43^{\mathrm{a}}$ & $3.80^{\mathrm{ba}}$ & 0.39 \\
\hline $\operatorname{ALT}(\mathrm{u} / \mathrm{ml})$ & $14.87^{\mathrm{e}}$ & $17^{\mathrm{d}}$ & $21.53^{\mathrm{a}}$ & $17.63^{\mathrm{cd}}$ & $19.77^{\mathbf{b}}$ & $18.87^{\mathfrak{c}}$ & 0.50 \\
\hline $\operatorname{AST}(\mathrm{u} / \mathrm{ml})$ & $23.67^{\mathrm{cb}}$ & $24.29^{\mathrm{a}}$ & $24.10^{\mathbf{a b}}$ & $22.38^{\text {cd }}$ & $23.67^{\mathrm{cb}}$ & $21.88^{\mathrm{d}}$ & 0.45 \\
\hline $\mathrm{Na}(\mathrm{mmol} / \mathrm{L})$ & $126.78^{\mathrm{c}}$ & $138.89^{\mathbf{b}}$ & $148^{\mathrm{a}}$ & $124.27^{\mathrm{d}}$ & $126.83^{c}$ & $121.93^{\text {ed }}$ & 0.60 \\
\hline $\mathrm{Cl}(\mathrm{mmol} / \mathrm{L})$ & $101^{b c}$ & $110.33^{\mathrm{a}}$ & $100^{\mathbf{b c}}$ & $102.83^{b}$ & $99^{d}$ & $102.33^{\mathbf{b}}$ & 0.54 \\
\hline $\mathrm{K}(\mathrm{mmol} / \mathrm{L})$ & $0.53^{\mathrm{ab}}$ & $0.29^{\mathrm{d}}$ & $0.57^{\mathbf{a b}}$ & $0.32^{\mathrm{c}}$ & $0.60^{\mathrm{a}}$ & $0.34^{\mathrm{c}}$ & 0.23 \\
\hline $\mathrm{Ph}(\mathrm{mmol} / \mathrm{L})$ & $10.47^{\mathrm{d}}$ & $20.83^{\mathrm{a}}$ & $20.83^{\mathrm{a}}$ & $16.67^{\mathrm{c}}$ & $18.23^{\mathbf{b}}$ & $18.27^{\mathbf{b}}$ & 0.49 \\
\hline
\end{tabular}

Table 3, showed that haematological and serum biochemical index as affected by heat stress in baladi and Shami goats. All obtained parameters of haematology showed a significant $(\mathrm{P}<0.05)$ influenced in treated goats. The haemoglobin $(\mathrm{Hb})$ concentration and red blood cell (RBC) showed a significant $(\mathrm{P}<0.05)$ increase at $\mathrm{T} 1$ in Baladi $(9.41$ $\mathrm{g} / \mathrm{dl}$ and $\left.10.37 \times 10^{12} / \mathrm{L}\right)$ and decrease value in Shami goats at T3 $\left(7.26 \mathrm{~g} / \mathrm{dl}\right.$ and $\left.8.30 \times 10^{12} / \mathrm{L}\right)$. The difference that observed may be assign to the high heat stress on goats which imparteda physiological need for raising in haemoglobin concentration and red blood cell to collaborate with the circulation of oxygen during panting. That explication was in regularity with the data obtained by Sanusi et al. (2010)who found increase in haemoglobin concentration and red blood cells number in sheep as a result of heat stress increasing. White blood cell (WBC) showed a significant $(\mathrm{P}<0.05)$ decrease at $\mathrm{T} 3$ in Baladi goats $\left(8.98 \times 10^{9} / \mathrm{L}\right)$ compared to $\mathrm{T} 2$ 
$\left(12.56 \times 10^{9} / \mathrm{L}\right)$ and $\mathrm{T} 1 \quad\left(11.70 \times 10^{9} / \mathrm{L}\right)$, otherwise, Shami goats showed increase at T3 $\left(9.65 \times 10^{9} / \mathrm{L}\right)$ compared with T2 $\left(6.98 \times 10^{9} / \mathrm{L}\right)$ and $\mathrm{T} 1\left(6.42 \times 10^{9} / \mathrm{L}\right)$. The variation in W.B.Cs may be as a result of rectal temperature and immunological challenged effects of the experimental goats which assign to modification in their physiology that found versus noxious the effect of antigen. The present result also was observed by Okoruwa et al. (2013) who found a significant $(\mathrm{P}<0.05)$ decrease in W.B.Cs for experimental dwarf bucks because of increase in rectal temperature. Biochemical results in serum also significantly $(\mathrm{P}<0.05)$ influenced by treated goats. Shami goats showed a significant $(\mathrm{P}<0.05)$ increase at $\mathrm{T} 1$ in total protein $(\mathrm{TP}, 12.37 \mathrm{~g} / \mathrm{dl})$, albumin (AL, $3.60 \mathrm{~g} / \mathrm{dl}$ ), Aspartate transferase (AST, 24.29u/ml), chloride $(\mathrm{Cl}, 110.33 \mathrm{mmol} / \mathrm{L})$ and Phosphorus $(\mathrm{Ph}$, $20.83 \mathrm{mmol} / \mathrm{L}$ ) compared with $\mathrm{T} 2$ and $\mathrm{T} 3$, and a significant $(\mathrm{P}<0.05) \quad$ increase in sodium $(\mathrm{Na}+, 138.89 \mathrm{mmol} / \mathrm{L})$ at $\mathrm{T} 2$, potassium $(\mathrm{K}$, $0.60 \mathrm{mmol} / \mathrm{L}$ )at $\mathrm{T} 3$. On the other hand, Baladi goats showed a significant $(\mathrm{P}<0.05)$ increase in albumin $(4.33 \mathrm{~g} / \mathrm{dl}), \operatorname{ALT}(21.53 \mathrm{u} / \mathrm{ml}), \operatorname{AST}(24.10 \mathrm{u} / \mathrm{ml}), \mathrm{Na}+$ $(148 \mathrm{mmol} / \mathrm{L}), \mathrm{K}(0.57)$ and $\mathrm{Ph}(20.83 \mathrm{mmol} / \mathrm{L})$ at $\mathrm{T} 2$ compared with T1 and T3, while TP showed increase at $\mathrm{T} 3(3.80 \mathrm{~g} / \mathrm{dl})$ and $\mathrm{Cl}$ induced increase at $\mathrm{T} 1$ and $\mathrm{T} 2$ (101 and $100 \mathrm{mmol} / \mathrm{l})$ respectively. The increased in serum concentration of total protein and AL in both breeds could be result of dehydration that happened as a result of raising the rate of breathing(Erickson and Poole, 2006). AI Qarawi et al., 2003 and Rashid et al., 2013 explained the observed the increase in ALT and AST explained by increasing uric acid in summer season due to the elevation of blood urea might be due to the combined pre-renal effects of reduced infusion with lower glomerular filtration and greatest load due to increased metabolic activity. The observed decreased of serum $\mathrm{K}+$ may be a result to the heat stress that stimulate activate secretion of cortical and the consequentstimulation of gluconegenesis and $\mathrm{K}+$ supprestion of cellular glucose uptake and profiteering(Marai et al., 2007). Pervious studied agreement with our data and reported that heat stressed animals lost more potassium and chloride in sweat than non-heat stressed animals (Aryal et al., 2012 and Hooda and Upadhyay, 2014). The decrease in electrolytes concentration observed in this study may also be due to expanded blood volume where water is transported in the circulatory system for evaporative cooling as suggested by A1-Haidary (2004).

\section{CONCLUSION}

The observed showed diversity on thermoregulatory, bodyweight and physiological parameters in the experimental animals, which were correlated with nature of the surrounding environment, type of goats and the variation in their exposed time to solar radiation. Thus, the results of this study correlate that local goat (Baladi) are more adaptable than foreign goats (Shami) to heat stress.
However goat's production under that status in Egypt and other parts of the world could demand ecologicaland nutritional adjustment to qualify the effect of heat stress on goats.

\section{REFERENCES}

Al-Eissa, M.S. and Alkahtani, S. (2011). Seasonal influence on some blood and biochemical parameters of Jerboa (Jaculus jaculus) in Saudi Arabia. J. Res. Opin Anim. and Vet. Sci., 1(5): 51-54.

Al-Haidary, A.A., Samara, E.M., Okah, A.B. and Abdoun, K.A. (2013). Thermophysiological responses and heat tolerance of Saudi camel breeds. Int. J. Chem. Environ. and Bio. Sci., 1(1): 173-176.

Al-Haidary, A.A., Aljumaah, R.S., Alshaikh, M.A., Abdoun, K.A., Samara, E.M., Okah, A.B. and Aluraiji, M.M. (2012). Thermoregulatory and physiological responses of Najdi sheep exposed to environmental heat load prevailing in Saudi Arabi. Pak. Vet. J., 32(4): 515-519.

AL-Haidary A.A. (2004). Physiological Responses of Naimey Sheep to Heat StressChallenge under Semi-Arid Environments. IJAB. 15608530/ 06-2-307-309.

Al-Qarawi A.A., Ali B.H., and Al-Mougy S.A. (2003). Gastrointestinal transit in mice treated with various extracts of date (Phoenix dactylifera L.).Food Chem Toxicol.41(1):37-9.

Amundson J.L, Mader T.L., Rasby R.J. and Hu Q.S. (2006). Environmental effects on pregnancy rate in beef cattle. J. Anim. Sci., 84: 34153420 .

Anaga, A.O., Shoyinka S.V.O., and Asuzu I..U. (2006). "Toxic Effects of Dennettia tripetala. Root Extract", Pharmaceutical Biology.

Aryal KK1, Joshi HD, Dhimal M, Singh SP, Dhakal P, Dhimal B, Bhusal CL. (2012). Environmental burden of diarrhoeal diseases due to unsafe water supply and poor sanitation coverage in Nepal. J Nepal Health Res Counc. 10(21):125-9.

Castanheira, M., Parva, S.R., Louvandini, H., Landim, A., Fiorvanti, M.C.S., Dallago, B.S., Correa, P.S. and McManus, C. (2010). Use of heat tolerance traits in discriminating between groups of sheep in central Brazil. Trop. Anim. Health Prod., 42: 1821-1828.

Erickson, H.H. and Poole, D.C. (2006). Fisiologia do exercicio. In: Dukes fisiologia dos animal domesticos. 12th Ed. (reece.wo.ed.). Rio de Janerio: Guanabara Koogan.

Helal, A., Hashem, A.L.S., Abdel-Fattah, M.S. and El-Shaer, H.M. (2010a). Effects of heat stress on coat characteristics and physiological responses of Balady and Damascus goats in Sinai, Egypt. American-Eurasian J. Agric. and Environ. Sci., 7(1): 60-69. 
Helal A., Youssef K.M., El-Shaer H.M., Gipson T.A., Goetsch A.L., Askar A.R.. (2010b). "Effects of acclimatization on energy expenditure by different goat genotypes", Livestock Science, 01 .

Hooda O.K., and Upadhyay R.C. (2014). Physiological Responses, Growth Rate and Blood Metabolites under Feed Restriction and Thermal Exposure in Kids. Journal of Stress Physiology \& Biochemistry. 10: 214-227.

Kalyan D.e., Davendra K., Vijay K.S., and Syed M.K.N. (2017). "Study of circadian rhythmicity of physiological response and skin temperature of sheep during summer and winter in semi-arid tropical environment", Physiology \& Behavior.

Marai, I.F.M., El-Darawany, A.A., Fadiel, A. and Abdel-Hafez, M.A.M. (2007). Physiological traits as affected by heat stress in sheep. A review. Small Rumin. Res., 71: 1-12.

McManus, C., Prescott, E., Paludo, G.R., Bianchini, E., Louvandini, H. and Mariante, A.S. (2009). Heat tolerance in naturalized Brazilian cattle breeds. Livest. Sci., 120: 256-264.

Ocak, S., Darcan, N., Cankaya, S. and Inal, T.C. (2009). Physiological and biochemical responses in German fawn kids subjected to cooling treatments under mediterranean climatic conditions. Turk J. Vet. Anim. Sci. 33(6): 455-461.

Okoruwa M.I. (2014). Effect of heat stress on thermoregulatory, live body weight and physiological responses of Dwarf goats in Southern Nigeria. European Scientific Journal. 10, $1857-7881$.

Okoruwa, M.I. and Ikhimioya, I. (2014). Haematological indices and serum biochemical profiles of dwarf goats fed elephant grass and varying levels of combined plantain with mango peels. American. J. Exp. Agric., 4(6): $619-628$.
Otoikhian C. S. O., OrheruataJ. A., Imasuen J. A. and AkporhuarhoO. P.(2009). Physiological response of local (West African Dwarf) and adapted Switzerland (White Bornu) goat breed to varied climatic conditions in South-South Nigeria. AJGA 2008068/5101.

Ozung P.O., Nsa E.E., Ebegbulem V.N. and Ubua J.A. (2011). The potentials of small ruminant production in Cross River rainforest zone of Nigeria: A review. Continental Journal of Animal and Veterinary Research, 3(1): 33-37.

Rashid M.M., Hossain M.M., Azad M.A.K., and Hashem M.A. (2013). Long term cyclic heat stress influences physiological responses and blood characteristics in indigenous sheep. Bang. J. Anim. Sci. 42 (2): 96-100.

Sanusi, A.O., Peter, S.O., Sonibare, A.O. and Ozojie, M.O. (2010). Effects of coat colour on heat stress among West African dwarf sheep. Nig. J. Anim. Prod., 38(1): 28-36.

Schutz, K.E., Roger, A.R., Cox, N.R., Webster, J.R. and Tucker, C.B. (2011). Dairy cattle prefer shade over sprinkler effects on behaviour and physiological. J. Dairy Sci., 94: 273-283.

Silanikove, N. (2000). "Effects of heat stress on thewelfare of extensively managed domestic ruminants", Livestock Production Science, 12.

Swarup D., Ram Naresh, VarshneyV.P., BalagangatharathilagarM., KumarP., NandiD., and Patra R.C. (2007). "Changes in plasma hormones profile and liver function in cows naturally exposed to lead and cadmium around different industrial areas", Research in Veterinary Science, 02

Tushar J., Swagat M., Chinmoy M., Nirupama D. and Akshya K.K. (2017). Heat tolerance in goat- A genetic update. The Pharma Innovation Journal; 6(9): 237-245.

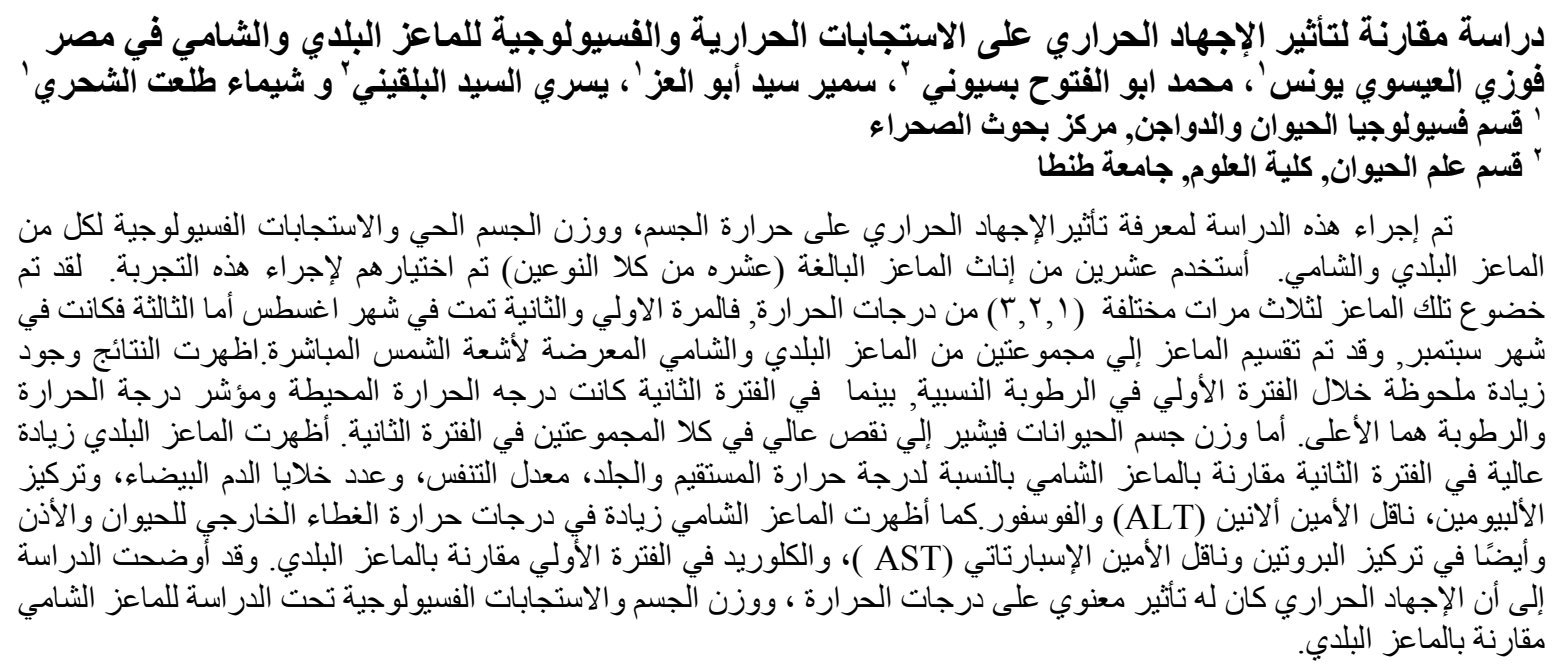

